\title{
Клінічний “портрет” хворого з гострим коронарним синдромом у поєднанні з критичною ішемією нижніх кінцівок як критерій прогнозування та вибору тактики лікування
}

\begin{abstract}
Мета роботи: визначити вплив атеростенотичного ураження клубово-стегнового артеріального сегмента на тяжкість клінічного перебігу, вираження змін лабораторно-інструментальних параметрів та прогноз у хворих на ГКС (IM) з елевацією сегмента ST. Матеріали і методи. Обстежено 105 хворих на ГКС (IM) з елевацією сегмента ST в поєднанні з критичною ішемією нижніх кінцівок (КIHK) внаслідок стенотичного атеросклерозу клубово-стегнового артеріального сегмента (III-IV ст. XAI) та 38 хворих на ГКС (IM) з елевацією сегмента ST без КIHK (група порівняння). Окрім загальноклінічних, лабораторних та інструментальних методів, додатково проводили ЕКГ, УЗД аорто-клубового та стегнового артеріальних сегментів, трансторакальну ЕхоКГ та КАГ для оцінки тяжкості анатомічного ураження ВА. Ризик внутрішньогоспітальної летальності прогнозували за шкалою GRACE. Результати досліджень та їх обговорення. На ГКС (IM) у поєднанні з КІНК суттєво частіше (у 73 \% випадків) хворіють чоловіки середнього і похилого віку (понад 55 років), які за гендерним цензом переважають над хворими жінками (10,7:1). Для них характерна наявність коморбідних станів (АГ, некомпенсованого ЦД 2 типу, МС, ХОЗЛ та таких факторів ризику ІХС, як дисліпідемія, куріння, вживання надмірних доз алкоголю та обтяжена спадковість).

Характерними рисами клінічного “портрету” хворого на ГКС (IM) з КІНК є тяжкий загальний стан хворого, який зумовлений наявністю комбінованого багатосудинного ураження вінцевих артерій (в 4,78 раза частіше, ніж при ізольованому ГКС) та більшим об’ємом міокардіального некрозу, ознаки гіпертрофії та ремоделювання з суттєвим зниженням систолічної (ФВ менше 50 \%) та діастолічної функцій. Часта наявність життєво загрозливих ускладнень гострого періоду ІМ (порушень ритму і провідності та гострої серцевої недостатності визначали прогнозування високого ризику смертності за шкалою GRACE (172,7士12,7 бала)).
\end{abstract}

Ключові слова: гострий коронарний синдром; критична ішемія нижніх кінцівок; діагностика; клінічні прояви; прогнозування; лікування.

Постановка проблеми і аналіз останніх досліджень та публікацій. Незважаючи на сучасні досягнення кардіології, в останні десятиліття серцево-судинні захворювання є основною причиною інвалідизації і смертності населення в економічно розвинених країнах [1]. В Україні поширення, захворюваність та смертність від патології системи кровообігу становила у 2017-2018 рр., відповідно, 63793, 4957 та 998 на 100 тис. населення, а ішемічна хвороба серця (IXC) та облітеруючий атеросклероз нижніх кінцівок займають провідне місце і досягають, відповідно, 22274, 1331 та 694 випадків на 100 тис. дорослого і працездатного населення [2]. 3'явилися статистичні та наукові дані, що супутній атеросклероз некоронарної локалізації є важливим фактором, який визначає клінічну тяжкість та прогноз хворого з IXC. Частота виявлення мультифокального атеросклерозу (МФА) варіює від 18 до 54 \%, а серед хворих на IXС він може досягати $90 \%$ [3-5].

Понад 50 \% таких пацієнтів госпіталізовують 3 ураженням не лише коронарних судин, а й, як правило, і облітеруючим атеросклеротичним ураженням артерій інших басейнів, що значно ускладнює клінічну ситуацію щодо визначення об’ єму та методики хірургічного втручання як на судинах серця, так i судинах нижніх кінцівок [6-8]. Актуальні Європейські та Американські рекомендації з лікування цих пацієнтів провідну роль відводять скороченню часу реперфузії, але не визначено черговість виконання i обсяг реваскуляризації, не розроблено чітких критеріїв прогнозування перебігу даної коморбідної патології та залишається надзвичайно високою частота розвитку ускладнень, які пояснюються концепцією мультифокальної ранимості атеросклеротичної бляшки (АСБ) під впливом як місцевих, так і зовнішніх та системних факторів [9, 10].

Можна передбачити, що врахування особливостей клінічного перебігу гострого коронарного синдрому (ГКС (IM)) на тлі атеросклеротичного артеріостенозу нижніх кінцівок, дослідження патогенетичних механізмів розвитку лабораторно-інструментальних змін у даних коморбідних пацієнтів дасть змогу виділити ранні діагностично-прогностичні критерії несприятливого перебігу хвороби і розробити адекватні програми лікування.

Мета роботи: визначити вплив критичної ішемії нижніх кінцівок внаслідок атеростенотичного ураження клубово-стегнового артеріального сегмента на тяжкість клінічного перебігу, вираження змін лабораторно-інструментальних параметрів та прогноз у хворих на ГКС (IM) з елевацією сегмента ST. 
Матеріали і методи. Дослідження проведено як відкрите, контрольоване, порівняльне у паралельних групах і базується на обстеженні 156 пацієнтів (105 хворих із ГКС (IM) з елевацією сегмента ST в поєднанні з критичною ішемією нижніх кінцівок (КIHK) внаслідок стенотичного атеросклерозу клубово-стегнового артеріального сегмента (IIIIV ст. XAI за Fontaine [11] і (ESC, 2017) [12] та 38 хворих на ГКС (IM) з елевацією сегмента ST без KIHK (група порівняння)). Діагноз гострого коронарного синдрому верифікували згідно з рекомендаціями уніфікованого протоколу МОЗ України [13] та ESC (2017) [14] при наявності типового ангінозного нападу, змін ЕКГ та ЕхоКГ і ознак некрорезорбтивного синдрому та підтверджувалися результатами ургентної коронароангіографії. Підтвердження діагнозу облітеруючого атеросклерозу магістральних судин нижніх кінцівок проводилося за допомогою клініко-лабораторних (вираження больового синдрому, ослаблення або відсутність пульсації артерій нижньої кінцівки, гіпотрофії м'язів гомілки і стегна, наявності трофічних змін у ділянці пальців та стоп тощо) та інструментальних методів обстеження (ультрасонографії та KTангіографії магістральних судин).

Окрім загальноклінічних, лабораторних та інструментальних методів (загального і біохімічного аналізів крові, ліпідограми, коагулограми, МВ фракції креатинфосфокінази (КФК-МВ), тропоніну $\mathrm{T}$, насичення артеріальної крові киснем $\left(\mathrm{SpO}_{2}\right)$ [15], ЕКГ у 12 стандартних відведеннях з моніторингом порушень ритму та провідності), додатково проводили визначення параметрів інтракардіальної гемодинаміки методом трансторакальної ЕхоКГ (Canon Aplio 400 із секторальним датчиком) у M-, В- та доплерівському режимах [16]. Результати інтерпретували в трьох напрямках: а) визначення стану внутрішньосерцевої гемодинаміки; б) типу структурно-геометричного ремоделювання лівого шлуночка; в) варіанту дисфункції міокарда.

Селективну поліпозиційну коронаровентрикулографію (КАГ) проводили за методикою M. Judkins (SIEMENS Axiom Artis, Німеччина) для оцінки ступеня звуження просвіту інфаркт-залежної вінцевої артерії, локалізації стенозу та кількості ураження судин за шкалами SS I, SS II. Тяжкість анатомічного ураження ВА визначали за шкалою "SYNTAX”: анатомічні ураження вважали легкими у разі нарахування $\leq 22$ балів, помірні -23-32 бали і тяжкі - $\geq 33$ балів [17].

Морфофункціональний стан аорто-клубового та стегнового артеріальних сегментів досліджували за допомогою УЗД з використанням лінійного датчика (5-15 МГц). Визначали прохідність артерії, діаметр і стан її просвіту та стінки, а також оцінювали систолічну і діастолічну швидкість кровотоку; індекс периферичного опору; індекс пульсації та систоло-діастолічне співвідношення (S/D), що характеризує стан (еластичність) артеріальної стінки.

Окрім того, в усіх пацієнтів оцінювали ризик внутрішньогоспітальної летальності та 6-місячної смертності за шкалою GRACE [18]. Ризик вважали дуже високим при наявності рефрактерної стенокардії, ГСН III-IV класу за Killip, життєво небезпечних шлуночкових аритмій або нестабільної гемодинаміки на момент госпіталізації (за їх наявності пацієнтам показано проведення невідкладного інвазивного лікування впродовж перших 2 годин); високим - за наявності > 140 балів за шкалою GRACE (показано раннє інвазивне лікування - впродовж 24 годин); помірним - 140-109 балів (пізнє або відстрочене інвазивне лікування впродовж 72 год) і низьким - < 109 балів (інвазивне лікування не показано).

Зазначені обстеження проводили при госпіталізації хворого і повторно безпосередньо після інтервенційного втручання та на 10-ту добу.

Статистичне опрацювання показників проводили методом варіаційної статистики. Вибірки перевіряли на нормальність розподілу даних за тестом Шапіро - Уїлка, застосовували параметричні (t-тест, критерій Ст’юдента) чи непараметричні (u-тест Манна - Уїтні) методи. Для оцінки зв’язку між ознаками визначали коефіцієнт кореляції (r) та критерій його вірогідності за методом Пірсона [19].

Результати досліджень та їх обговорення. Основні клініко-анамнестичні дані обстежених груп хворих на ГКС (IM) та ГКС (IM) в поєднанні 3 критичною ішемією нижніх кінцівок внаслідок атеросклеротичного артеріального стенозу клубово-стегнового сегмента подано в таблиці 1.

Наведена вікова та гендерна характеристика обстежених хворих свідчить, що віковий профіль пацієнтів був статистично однаковим в основній групі та в групі порівняння і становив у серед-

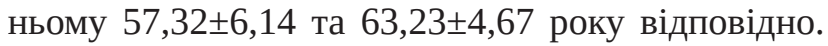
Гендерний склад дослідних груп був також однорідним, кількість хворих чоловіків суттєво переважала над хворими жіночої статі (відповідно, 10,7:1 i 4,4:1), але в основній групі жінок було в 2,4 раза менше, ніж у групі порівняння. В обох групах суттєво переважали пацієнти середнього і похилого віку (63,8 \% і 9,5 \% та 68,4 \% і 13,2 \%, відповідно), які складали більшість (73,3 \% і 81,6 \%, відповідно) у обстежених групах хворих (різниця між групами за критерієм $\chi^{2}$ високодостовірна, $\left.\mathrm{p}<0,001\right)$. 
Таблиця 1. Клініко-анамнестичні дані обстежених груп хворих

\begin{tabular}{|c|c|c|c|}
\hline Показник & $\begin{array}{c}\text { Параметри в основній групі } \\
\text { (гострого коронарного синдрому } \\
\text { (інфаркту міокарда) з критичною } \\
\text { ішемією нижніх кінцівок), } \\
\text { n = } 105\end{array}$ & $\begin{array}{c}\text { Параметри в групі порівняння } \\
\text { (гострого коронарного синдрому } \\
\text { (інфаркту міокарда) без критичної } \\
\text { ішемії нижніх кінцівок), } \\
\text { n = } 38\end{array}$ & $\mathrm{P}$ \\
\hline \multicolumn{4}{|c|}{ Вік хворих (роки) } \\
\hline Середній вік: & $57,32 \pm 6,14$ & $63,23 \pm 4,67$ & $>0,05$ \\
\hline до 45 & $28(26,7 \%)$ & $7(18,4 \%)$ & $>0,05$ \\
\hline $46-60$ & $67(63,8 \%)$ & $26(68,4 \%)$ & $>0,05$ \\
\hline Понад 60 років & $10(9,5 \%)$ & $5(13,2 \%)$ & $>0,05$ \\
\hline \multicolumn{4}{|c|}{ Стать } \\
\hline $\begin{array}{l}\text { Чоловіків } \\
\text { Жінок }\end{array}$ & $\begin{array}{c}96(91,4 \%) \\
9(8,6 \%)\end{array}$ & $\begin{array}{c}31(81,6 \%) \\
7(18,4 \%)\end{array}$ & $\begin{array}{l}>0,05 \\
>0,05\end{array}$ \\
\hline \multicolumn{4}{|c|}{ Локалізація зони ушкодження (некрозу) } \\
\hline $\begin{array}{l}\text { Перегородково- } \\
\text { верхівкова }\end{array}$ & $41(39,1 \%)$ & $14(36,8 \%)$ & $>0,05$ \\
\hline Задньодіафрагмальна & $48(45,7 \%)$ & $17(44,7 \%)$ & $>0,05$ \\
\hline Бокова (базальна) & $16(15,2 \%)$ & $7(18,4 \%)$ & $>0,05$ \\
\hline \multicolumn{4}{|c|}{ Фактори ризику } \\
\hline Артеріальна гіпертензія & $102(97,1 \%)$ & $20(78,9 \%)$ & $<0,05$ \\
\hline Куріння 5 та більше років & $76(74,2 \%)$ & $17(44,7 \%)$ & $<0,05$ \\
\hline $\begin{array}{l}\text { Дис- або } \\
\text { гіперхолестеринемія }\end{array}$ & $102(97,1 \%)$ & $31(81,6 \%)$ & $<0,05$ \\
\hline $\begin{array}{l}\text { Надлишкова маса тіла } \\
\text { або ожиріння }\end{array}$ & $34(32,4 \%)$ & $17(44,7 \%)$ & $<0,05$ \\
\hline Цукровий діабет 2 тип & $36(34,3 \%)$ & $9(23,7 \%)$ & $<0,05$ \\
\hline $\begin{array}{l}\text { Комбінація } 2 \text { і більше } \\
\text { Факторів ризику }\end{array}$ & $86(81,9 \%)$ & $14(36,8 \%)$ & $<0,05$ \\
\hline \multicolumn{4}{|c|}{ Хронічна серцева недостатність } \\
\hline І стадія (II ФК) & 19 ( $18,1 \%)$ & $14(36,8 \%)$ & $<0,05$ \\
\hline IIA стадія (III ФК) & $52(49,5 \%)$ & $18(47,4 \%)$ & $>0,05$ \\
\hline IIA стадія (IV ФК) & $34(32,4 \%)$ & $6(15,8 \%)$ & $<0,05$ \\
\hline \multicolumn{4}{|c|}{ Гостра серцева недостатність (ступінь за T. Killip ) } \\
\hline І кл. & $13(12,4 \%)$ & 17 (44,7 \%) & $<0,05$ \\
\hline II кл. & $26(24,8 \%)$ & $9(23,7 \%)$ & $>0,05$ \\
\hline III кл. & 34 (32,3 \%) & $8(21,1 \%)$ & $<0,05$ \\
\hline IV кл. & $32(30,5 \%)$ & $4(10,5 \%)$ & $<0,05$ \\
\hline
\end{tabular}

Примітка. Кількість хворих вказана в абсолютних числах, в дужках - відсоток до загальної кількості осіб. 
3 типовим ангінозним синдромом госпіталізували 81,9 \% пацієнтів основної групи та 76,3 \% хворих групи порівняння, відповідно, у 21,9 \% та $18,4 \%$ больовий синдром був атиповим. Іррадіація болю в епігастральну ділянку або ліву руку спостерігали, відповідно, у 53,3 \% та 42,1 \% пацієнтів. Виражена загальна слабкість мала місце у 62,9 \% та 60,5 \% обстежених, близько 35 \% пацієнтів обох груп скаржилися на дискомфорт у грудях та задишку, відчуття нестачі повітря. У 5,7 \% та 7,9 \% хворих відповідних груп спостерігали нудоту, блювання та головокружіння. Важливо зазначити, що дебют захворювання у 48,6 \% пацієнтів основної групи та в 42,1 \% хворих групи порівняння був пов'язаний із фізичним навантаженням, в 31,4 \% та 28,9 \% - з психоемоційним стресом і в решти хворих ГКС розвився в стані спокою або на тлі різкого підвищення АТ. Встановлено, що у більшості пацієнтів (відповідно, у 53,3 \% та 52,6 \%) захворювання розпочалось у активний період доби, у 20,9 \% та 23,7 \% - вночі (уві сні) та у 25,8 \% і 23,7 \% - вранці.

Проаналізовано також своєчасність госпіталізації та проведення реперфузійного лікування за методикою перкутанного коронарного втручання (ПКВ) у пацієнтів обстежених груп (табл. 2). При цьому зауважимо, що до 12 годин від початку ангінозного нападу госпіталізовано 73,7 \% хворих 3 ізольованим ГКС (IM) і 69,5 \% хворих з ГКС (IM) в поєднанні з KIHK. Разом із тим, треба вказати на факт більш пізньої частоти госпіталізації (після 24 год) хворих на ГКС (IM) у поєднанні з КIHK, що можна пояснити тяжчим клінічним станом цих пацієнтів та атиповістю клінічної картини ГКС.

У пацієнтів основної групи реваскуляризацію міокарда шляхом ПКВ та первинного стентування ВА проведено в середньому через $(10,43 \pm 1,32)$ годин з моменту появи ангінозного синдрому, а у хворих групи порівняння - через $(6,27 \pm 1,24)$ годин. При цьому зауважимо, що реперфузійні ускладнення достовірно частіше розвивались у хворих на ГКС (IM) у поєднанні з КІНК. Так, у пацієнтів цієї групи досить часто (у 17,1 \% випадків) діагносту- вали синдром подовженого/вкороченого інтервалу QT, з яким більшість дослідників пов'язує високу частоту розвитку життєво загрозливих шлуночкових аритмій. Гострий тромбоз стента розвинувся у 2 хворих із супутнім ЦД 2 типу. Загалом, у пацієнтів основної групи кількість ускладнень була в 2,1 раза вища, ніж у групі хворих з ізольованим ГКС (IM) без критичної ішемії нижніх кінцівок.

Для оцінки тяжкості ГСН в гострому періоді IM використовували клінічну класифікацію T. Killip, J. Kimball (1975). Оцінюючи початок ГКС (IM) STEMI відзначимо, що у 12,4 \% коморбідних хворих у поєднанні з КІНК та у 44,7 \% з ізольованим ГКС мала місце гостра серцева недостатність класу Killip I, у 25 \% та 23,7 \%, відповідно діагностували клас Killip II, у 32,4 \% та 21,1 \% - Killip III і в $30,5 \%$ та 10,5 \% - Killip IV.

Визначаючи наявність та частоту коморбідних станів та супутніх захворювань, які могли суттєво впливати на перебіг основного захворювання, було встановлено, що найчастіше патологією була артеріальна гіпертензія (АГ) - у 84,8 \% та 78,9 \% обстежених відповідних груп. Друге місце за поширенням серед хворих посідав цукровий діабет 2 типу (34,3 \% та 23,7 \%). Результати скринінгового аналізу показників вуглеводного обміну (А1cHb) показали, що рівень A1cHb при ЦД 2 типу у пацієнтів 3 ГКС (IM) в поєднанні з КІНК становив 8,35 $\pm 0,08 \%$, а у осіб з ізольованою ГКС (IM) - 7,18 $\pm 0,23 \%$ ( $<0,05)$, що свідчило про недостатній контроль компенсації гіперглікемії у хворих на ГКС (IM) в поєднанні з КІНК. Досить часто ГКС розвивався на тлі надлишкової маси тіла або ожиріння, які діагностували у 34 (32,4 \%) пацієнтів основної групи та у 17 (44,7 \%) хворих групи порівняння. Рідше в числі коморбідної патології зустрічались хронічне обструктивне захворювання легень (ХОЗЛ) (15,2 \% та 13,2 \%), хвороби нирок (17,1 \% та 7,9 \%) і дисфункція щитоподібної залози (у 11,4 \% та 7,9 \%). Що стосується поширеності основних ФР IXC у обох дослідних групах, то було встановлено, що окрім АГ, як найбільш поширеного ФР розвитку IXC,

Таблиця 2. Своєчасність госпіталізації пацієнтів із гострим коронарним синдромом у поєднанні

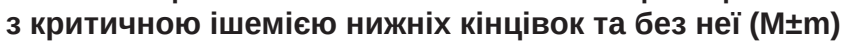

\begin{tabular}{|c|c|c|c|c|c|}
\hline \multirow{2}{*}{$\begin{array}{c}\text { Час від початку } \\
\text { ангінозного болю }\end{array}$} & \multicolumn{2}{|c|}{ Основна група, n=105 } & \multicolumn{2}{|c|}{ Група порівняння, n=38 } & \multirow{2}{*}{$\mathrm{P}$} \\
\hline & $\mathrm{n}$ & $\%$ & $\mathrm{n}$ & $\%$ & \\
\hline До 6 год & 17 & 16,2 & 13 & 34,2 & $<0,05$ \\
\hline 6-12 год & 56 & 53,3 & 15 & 39,5 & $>0,05$ \\
\hline 12-24 год & 37 & 35,2 & 9 & 23,7 & $>0,05$ \\
\hline Понад 24 год & 16 & 15,2 & 1 & 2,6 & $<0,05$ \\
\hline
\end{tabular}


в обстежених пацієнтів встановлено часте щоденне активне чи пасивне куріння у 72,4 \% пацієнтів I групи та у 44,7 \% осіб II групи (p<0,05). Частка осіб із дисліпідемією була також достовірно вища у пацієнтів основної групи порівняно з особами групи порівняння (97,1 \% проти 81,6 \%) (p<0,01). Не було виявлено достовірної різниці між хворими дослідних груп щодо таких ФР розвитку IXC, як обтяжена спадковість (відповідно, 27,6 \% і 23,7 \%, р>0,05) та вживання надмірних доз алкоголю (відповідно, у $31,4 \%$ та 23,7 \%, p>0,05).

Порушення ритму і провідності серця діагностували у 103 (98,1\%) обстежених хворих основної групи та у 32 (84,2 \%) пацієнтів групи порівняння. Найчастіше реєстрували шлуночкові або суправентрикулярні екстрасистоли (відповідно, у 80
(80,1 \%) хворих I групи і у 25 (65,8 \%) II групи), пароксизми фібриляції передсердь (у 32 (30,5 \% i 5 (13,2 \%)), шлуночкову тахікардію (у 12 (11,4 \% i 1 (2,6 \%)), блокади різного ступеня та локалізації (відповідно, у 43 (40,9 \%) пацієнтів основної групи і 7 (18,4 \%) групи порівняння). Встановлено пряму помірну залежність частоти та тяжкості порушень ритму і провідності від величини площі (об’єму) міокардіального некрозу, визначених за величиною елевації сегмента ST, підвищенням рівнів креатинінфосфокінази та тропоніну Т в плазмі крові $(\mathrm{r}=0,261-0,415)$. Разом із тим, достовірної різниці в силі кореляційних зв'язків у хворих з обстежених груп не виявлено.

Результати вихідного Ехо-КГ дослідження пацієнтів (табл. 3) свідчать, що вихідні показники ехо-

Таблиця 3. Сонографічні вихідні показники морфофункціонального стану серця в обстежених групах

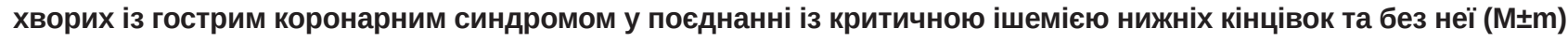

\begin{tabular}{|c|c|c|c|}
\hline Показники & $\begin{array}{c}\text { Основна група (гострий } \\
\text { коронарний синдром (інфаркт } \\
\text { міокарда) з критичною } \\
\text { ішемією нижніх кінцівок), } \\
\text { n=105 }\end{array}$ & $\begin{array}{c}\text { Група порівняння (гострий } \\
\text { коронарний синдром (інфаркт } \\
\text { міокарда) без критичної } \\
\text { ішемії нижніх кінцівок), n=38 }\end{array}$ & P \\
\hline $\begin{array}{l}\text { ТЗСлш, см } \\
(1,10 \pm 0,04)\end{array}$ & $1,16 \pm 0,04$ & $1,09 \pm 0,05$ & $>0,05$ \\
\hline $\begin{array}{l}\text { ТМШП, см } \\
(1,12 \pm 0,09)\end{array}$ & $1,15 \pm 0,06$ & $1,12 \pm 0,12$ & $>0,05$ \\
\hline 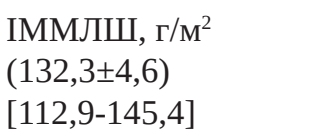 & $\begin{array}{c}162,6 \pm 5,4 \\
{[143,6-177,9]}\end{array}$ & $\begin{array}{c}151,2 \pm 4,8 \\
{[122,8-161,7]}\end{array}$ & $\begin{array}{l}<0,05 \\
<0,05\end{array}$ \\
\hline $\begin{array}{l}\text { КДОлш, мл } \\
(132,3 \pm 1,4)\end{array}$ & $156,4 \pm 1,4$ & $148,7 \pm 1,5$ & $<0,05$ \\
\hline $\begin{array}{l}\text { КСОлш, мл } \\
(79,4 \pm 2,4)\end{array}$ & $89,9 \pm 2,6$ & $81,3 \pm 3,8$ & $<0,05$ \\
\hline $\begin{array}{l}\text { IVRT, мс } \\
(88,5 \pm 2,1)\end{array}$ & $80,7 \pm 1,3$ & $84,7 \pm 1,1$ & $<0,05$ \\
\hline $\begin{array}{l}\text { DT, мс } \\
(186,4 \pm 4,1)\end{array}$ & $238,6 \pm 5,1$ & $199,7 \pm 4,2$ & $<0,05$ \\
\hline $\begin{array}{l}\text { Е, см/с } \\
(45,67 \pm 1,7)\end{array}$ & $65,7 \pm 1,8$ & $60,4 \pm 1,3$ & $<0,05$ \\
\hline $\begin{array}{l}\mathrm{A}, \mathrm{cм} / \mathrm{c} \\
(34,8 \pm 1,1)\end{array}$ & $43,8 \pm 1,2$ & $36,6 \pm 1,1$ & $<0,05$ \\
\hline $\begin{array}{l}\mathrm{E} / \mathrm{A} \\
(1,23 \pm 0,04)\end{array}$ & $1,46 \pm 0,04$ & $1,89 \pm 0,05$ & $<0,05$ \\
\hline $\begin{array}{l}\text { ФВ, \% } \\
(61,4 \pm 0,3)\end{array}$ & $47,8 \pm 0,5$ & $53,2 \pm 0,4$ & $<0,05$ \\
\hline
\end{tabular}

Примітка. В дужках наведено параметри показників в групі контролю (n=26). 
кардіограми у основної групи хворих із ГКС (IM) в поєднанні з КІНК суттєво відрізняють від аналогічних у здорових людей і в групі хворих з ізольованим ГКС (IM) без КІНК внаслідок стенотичного атеросклерозу клубово-стегнового артеріального сегмента. Встановлено достовірне зростання індексу маси міокарда лівого шлуночка та його об'єму за рахунок збільшення діастолічних і систолічних розмірів, що свідчило про гіпертрофію ЛШ та його ремоделювання. Наслідком цих процесів стало суттєве порушення систоло-діастолічної функції серця у обстежених груп хворих, а отримані достовірні відмінності результатів кардіогемодинаміки між дослідними групами хворих на ГКС (IM) із КІНК та без неї спонукали нас до роздільного дослідження ефективності медикаментозних та відновних програм лікування цих групах хворих.

За результатами ургентної коронароангіографії (КАГ) у хворих на ГКС (IM) в поєднанні з КІНК та без неї було встановлено заключний діагноз для кожного хворого та констатовано, що кількість та анатомічна виразність ураження коронарних артерій дещо відрізнялася за частотою та виразністю оклюзій окремих сегментів між обстеженими групами хворих (табл. 4).

Так, комбіноване багатосудинне ураження вінцевих артерій серця суттєво частіше зустрічалось (в 4,78 раза) у коморбідних хворих на ГКС (IM) у поєднанні з КIHK внаслідок стенотичного атеросклерозу клубово-стегнового артеріального сегмента. В пацієнтів основної групи у 81,9 \% випадків домінували двосудинні або багатосудинні ураження ВА, тоді як у пацієнтів групи порівняння їх було виявлено лише у 47,3 \% осіб $(\mathrm{p}<0,05)$. Односудинні ураження ВА були у $18 \%$ хворих із ГКС (IM) в поєднанні з КІНК, проти, відповідно, 47,4 \% у хворих без KIHK (р>0,05). Особливо велику різницю спостерігали щодо частоти багато- судинних уражень ВА у групі хворих на ГКС (IM) в поєднанні з KIHK (49,5 \% проти 10,5 \% у осіб групи порівняння $(\mathrm{p}<0,05))$.

Розрахований бал за шкалою GRACE в пацієнтів із ГКС (IM) в поєднанні з КІНК коливався

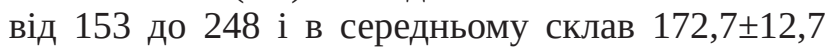
(медіана 160, інтерквартильний розмах 129 і 193). При цьому в більшості цих пацієнтів $(78,0$ \%) визначали високий ризик смертельних наслідків у найближчий період (>140 балів за шкалою і ризик смерті $>5 \%$ ) і лише у $12 \%$ низький (<140 балів за шкалою і ризик смерті < 3 \%). Навпаки, у хворих з ізольованим ГКС (IM) без КІНК високий ризик смертельних наслідків у найближчий період визначали у 34,0 \% випадків, а кількість пацієнтів із помірним і низьким ризиком становила $66 \%$. Тому всім пацієнтам обох обстежених груп відповідно до рекомендацій Асоціації кардіологів України (2014) і ESC/EACTS (2017) у термін від 1 до 24 год від моменту госпіталізації були проведені коронаровентрикулографія та імплантовано від 1 до 3 стент-систем.

Таким чином, на ГКС (IM) в поєднанні з КIHK суттєво частіше (у 73 \% випадків) хворіють чоловіки середнього і похилого віку (понад 55 років), які за гендерним цензом переважають над хворими жіночої статі у співвідношенні 10,7:1. Для цих пацієнтів характерна часто наявність коморбідних станів - артеріальної гіпертензії - у 84,8 \%, некомпенсованого цукрового діабету 2 типу - у 34,3%, метаболічного синдрому - у 32,4 \%, хронічної хвороби нирок - у 17,1 \%, ХОЗЛ - у 15,2 \%, дисфункції щитоподібної залози - у 11,4 \% та таких факторів ризику IXC (та їх комбінацій) як атерогенна дисліпідемія - у 97,1 \%, куріння тютюну - у 72,4 \%, вживання надмірних доз алкоголю у $31,4 \%$ та обтяжена спадковість щодо IXC - y 27,6 \% пацієнтів.

Таблиця 4. Стан коронарного русла у пацієнтів із гострим коронарним синдромом (інфарктом міокарда) у поєднанні з критичною ішемією нижніх кінцівок та без неї

\begin{tabular}{|c|c|c|c|c|c|}
\hline \multirow[t]{2}{*}{ Показники } & \multicolumn{2}{|c|}{$\begin{array}{c}\text { Хворі на гострий коронарний } \\
\text { синдром (інфаркт міокарда) з } \\
\text { критичною ішемією нижніх } \\
\text { кінцівок, n = } 105\end{array}$} & \multicolumn{2}{|c|}{$\begin{array}{c}\text { Хворі на гострий коронарний } \\
\text { синдром (інфаркт міокарда) } \\
\text { без критичної ішемії нижніх } \\
\text { кінцівок, n = } 38\end{array}$} & \multirow[t]{2}{*}{$\mathrm{P}$} \\
\hline & $\mathrm{n}$ & $\%$ & $\mathrm{n}$ & $\%$ & \\
\hline Відсутність уражень & 0 & 0 & 2 & 5,3 & $<0,05$ \\
\hline Односудинне ураження & 19 & 18,1 & 18 & 47,4 & $<0,05$ \\
\hline Двосудинне ураження & 34 & 32,4 & 14 & 36,8 & $>0,05$ \\
\hline Багатосудинні ураження & 52 & 49,5 & 4 & 10,5 & $<0,05$ \\
\hline
\end{tabular}


Характерними рисами “портрету” хворого на ГКС (IM) з КIHК є виражені прояви даної коморбідної патології та тяжкий загальний стан хворого, які зумовлені наявністю комбінованого багатосудинного ураження вінцевих артерій (в 4,78 раза частіше, ніж при ізольованому ГКС) та більшою площею (об’ємом) міокардіального некрозу, про що свідчить більш виражені прояви некрорезорбтивного синдрому. 3 цих же причин у хворих на ГКС (IM) в поєднанні з КІНК встановлено достовірне зростання маси міокарда лівого шлуночка та його об'єму за рахунок збільшення діастолічного та систолічного розмірів, що свідчить про гіпертрофію та ремоделювання серця з порушенням систолічної (ФВ менше 50 \%) та діастолічної функції у вигляді порушення процесів розслаблення.

Тяжкість клінічного стану хворого, зумовленого у 62,9 \% випадків ГСН III-IV ст., та пізня госпіталізація (понад 24 год від початку ангінозного нападу) у 50,4 \% випадків із-за атиповості дебюту захворювання (у 22 \% випадків) визначали прогнозування високого ризику смертності за шкалою GRACE (172,7 $\pm 12,7$ бала) та таких життєво загрозливих ускладнень гострого періоду IM, як порушень ритму та провідності (у 47,6 \%), різних варіантів гострої серцевої недостатності (у 17,1%), гострої аневризми лівого шлуночка (у 13,3 \%) тощо.

\section{СПИСОК ЛІТЕРАТУРИ}

1. Коваленко В. М. Актуальні проблеми здоров'я та мінімізація їх в умовах збройного конфлікту в Україні : посіб. / В. М. Коваленко, В. М. Корнацький. - Київ : “Національний науковий центр інститут кардіології ім. акад. М. Д. Стражеска”, 2019. - 216 с.

2. Гандзюк В. А. Динаміка захворюваності і смертності внаслідок хвороб системи кровообігу в Україні (регіональний аспект) / В. А. Гандзюк, Д. Д. Дячук, Н. Ю. Кондратюк // Вісник проблем біол. і мед. - 2017. - № 2 (136). - С. 319-322. 3. Сердечно-сосудистые заболевания в РФ на рубеже веков: смертность, распространенность, факторы риска / Л. А. Бокерия, И. Н. Ступаков, И. В. Самородская, Ю. М. Ботнарь // Бюлл. НЦССХ им. А. Н. Бакулева РАМН. Сердечно-сосудистые заболевания. - 2007. - № 8. - С. 5-11.

4. Распространенность и клиническая значимость мультифокального атеросклероза у пациентов с ишемической болезнью сердца / О. Л. Барбараш, М. В. Зыков, В. В. Кашталап, И. С. Барбараш // Кардиология. - 2011. - № 8. - С. 66-71.

5. Зыкова Д. С. Клинико-прогностическая значимость мультифокального атеросклероза, факторов неспецифического воспаления и полиморфизма генов у больных острым коронарным синдромом : автореф. дисс. на соискание науч. степ. канд. мед. наук / Д. С. Зыкова. - Кемерово, 2013. - 23 с.

6. Геник С. М. Реперфузійний синдром після реваскуляризації ішемії нижніх кінцівок / С. М. Геник, А. В. Симчич // Серце і судини. - 2016. - № 3. - С. 104-108.

7. Григорьев А. М. Факторы риска неблагоприятных исходов коронарного шунтирования у пациентов с изолирован-
Отже, інформація про повний клінічний “портрет” хворого на ГКС (IM) в поєднанні з КІНК внаслідок стенотичного атеросклерозу клубово-стегнового артеріального сегмента і розуміння патогенетичних механізмів “погіршання” його рис (ознак) буде сприяти своєчасній ранній діагностиці даної коморбідної патології та оптимізації вибору адекватної лікувальної тактики для конкретного пацієнта.

Висновки. Для клінічного “портрету” хворих на ГКС (IM)-STEMI в поєднанні з критичною ішемією нижніх кінцівок (КІНК) внаслідок стенотичного атеросклерозу клубово-стегнового артеріального сегмента характерні такі ознаки: чоловіки віком понад 55 років, з коморбідними станами та множинними факторами ризику IXC, багатосудинним і гемодинамічно тяжким ураженням вінцевих судин (понад 33 бали за шкалою “SYNTAX”), великою площею (об’ємом) міокардіального некрозу, що, в кінцевому результаті, визначає тяжкість перебігу хвороби, низький функціональний стан серцево-судинної системи та достовірно вищу частоту розвитку життєво загрозливих ускладнень в гострому періоді інфаркту міокарда та високий ризик (понад 160 балів за шкалою GRACE) серцевої смерті. ным и мультифокальным атеросклерозом : автореф. дисс. на соискание науч. степ. канд. мед. наук / А. М. Григорьев. - Кемерово, 2014. - 21 с.

8. Синьков М. А. Эффективность первичного ЧКВ у больных инфарктом миокарда и сопутствующим мультифокальным атеросклерозом : автореф. дисс. на соискание науч. степ. канд. мед. наук / М. А. Синьков. - Новосибирск, 2011. - 23 с. 9. Van der Wal A. C. Coronary artery pathology / A. C. Van der Wal // Heart. - 2007. - Vol. 93 (11). - P. 1484-1489.

10. Endovascular revascularization and supervised exercise for peripheral artery disease and intermittent claudication: a randomized clinical trial / F. Fakhry, S. Spronk, L. van der Laan [et al.] // JAMA. - 2015. - Vol. 314 (18). - P. 1936-1944.

11. Evolocumab and clinical outcomes in patients with cardiovascular disease / M. S. Sabatine, R. P. Giugliano, A. C. Keech [et al.] // N. Engl. J. Med. - 2017. - Vol. 376 (18). - P. 1713-1722.

12. Twelve-month results of a randomized trial comparing mono with dual antiplatelet therapy in endovascularly treated patients with peripheral artery disease / F. F. Strobl, K. Brechtel, J. Schmehl [et al.] // J. Endovasc. Ther. - 2013. - Vol. 20 (5). - P. 699-706. 13. Уніфікований клінічний протокол екстреної, первинної, вторинної та третинної медичної допомоги “Гострий коронарний синдром з елевацією сегмента ST” : наказ Міністерства охорони здоров’я України від 02.07.2014 № 455. - 78 с.

14. 2017 ESC Guidelines for the management of acute myocardial infarction in patients presenting with ST-segment elevation: The Task Force for the management of acute myocardial infarction in patients presenting with ST-segment elevation of the Euro- 
pean Society of Cardiology (ESC) / B. Ibanez, S. James, S. Agewall [et al.] // Eur. Heart J. - 2018. - Vol. 39 (2). - P. 119-177. DOI: https://doi.org/10.1093/eurheartj/ehx393.

15. Карпищенко А. И. Медицинская лабораторная диагностика (программы и алгоритмы) / А. И. Карпищенко // Медицинские лабораторные технологии и диагностика. - СПб. : Интермедика, 2001. - 124 с.

16. ACCF/ASE/AHA/ASNC/HFSA/HRS/SCAI/SCCM/SCCT/ SCMR 2011 appropriate use criteria for echocardiography / P. S. Douglas, M. J. Garcia, D. E. Haines [et al.] // J. Am. Soc. Echocardiogr. - 2011. - Vol. 24 (3). - P. 229-267.

\section{REFERENCES}

1. Kovalenko, V.M., \& Kornatskyi, V.M. (2019). Aktualni problemy zdorovia ta minimizatsiia yikh $v$ umovakh zbroinoho konfliktu v Ukraini (posib.) [Actual health problems and their minimization in the conditions of armed conflict in Ukraine (manual)]. Kyiv: "Natsionalnyi naukovyi tsentr instytut kardiolohiii im. akad. M. D. Strazheska” [in Ukrainian].

2. Handzyuk, V.A., Diachuk, D.D., \& Kondratiuk, N.Yu. (2017). Dynamika zakhvoriuvanosti i smertnosti vnaslidok khvorob systemy kovoobihu v Ukraini (rehionalnyi aspekt) [Dynamics of morbidity and mortality due to diseases of the circulatory system in Ukraine (regional aspect)]. Visnyk problem biolohii i medytsyny - Bull. of Problems of Biology and Medicine, 2 (136), 319-322 [in Ukrainian].

3. Bokeriya, L.A., Stupakov, I.N., Samorodskaya, I.V., \& Botnar, Yu.M. (2007). Serdechno-sosudistyye zabolevaniya v RF na rubezhe vekov: smertnost, rasprostranennost, faktory riska [Cardiovascular diseases in the Russian Federation at the turn of the century: mortality, prevalence, risk factors]. Byulleten Natsionalnogo nauchno-prakticheskogo tsentra serdechno-sosudistoy khirurgii imeni A.N. Bakuleva Ministerstva zdravokhraneniya Rossiyskoy Federatsii - National Scientific and Practical Center for Cardiovascular Surgery named after A.N. Bakulev of the Ministry of Health of the Russian Federation Bulletin, 8, 5-11 [in Russian]. 4. Barbarash, O.L., Zykov, M.V., Kashtalap, V.V., \& Barbarash, I.S. (2011). Rasprostranennost i klinicheskaya znachimost multifokalnogo ateroskleroza u patsiyentov s ishemicheskoy boleznyu serdtsa [Prevalence and clinical significance of multifocal atherosclerosis in patients with coronary heart disease]. Kardiologiya - Cardiology, 8, 66-71 [in Russian].

5. Zykova, D.S. (2013). Kliniko-prognosticheskaya znachimost multifokalnogo ateroskleroza, faktorov nespetsificheskogo vospaleniya i polimorfizma genov u bolnykh ostrym koronarnym sindromom [Clinical and prognostic significance of multifocal atherosclerosis, factors of nonspecific inflammation and gene polymorphism in patients with acute coronary syndrome]. Candidate's thesis. Kemerovo [in Russian].

6. Henyk, S.M., \& Symchych, A.V. (2016). Reperfuziinyi syndrom pislia revaskuliaryzatsii ishemii nyzhnikh kintsivok [Reperfusion syndrome after revascularization of lower extremity ischemia]. Sertse i sudyny - Heart and Vessels, 3, 104-108 [in Ukrainian].

7. Grigoryev, A.M. (2014). Faktory riska neblagopriyatnykh iskhodov koronarnogo shuntirovaniya u patsiyentov s izolirovannym i multifokalnym aterosklerozom [Risk factors for unfavorable outcomes of coronary artery bypass grafting in patients with isolated and multifocal atherosclerosis]. Candidate's thesis. Kemerovo [in Russian].
17. Papadopoulos $\mathrm{K}$. The predictive value of the syntax score in patients with chronic coronary artery disease undergoing percutaneous coronary intervention or coronary artery bypass grafting: a pilot study / K. Papadopoulos, I. Lekakis, E. Nicolaides // Open Cardiovasc. Med. J. - 2017. - Vol. 11. - P. 28-32.

18. An international randomized trial comparing four thrombolytic strategies for acute myocardial infarction // N. Engl. J. Med. - 2010. - Vol. 329 (10). - P. 673-682.

19. Реброва О. Ю. Статистический анализ медицинских данных / О. Ю. Реброва // Применение пакета прикладных программ STATISTICA. - Москва : МедиаСфера, 2006. - 312 с.

8. Sinkov, M.A. (2011). Effektivnost pervichnogo ChKV u bolnykh infarktom miokarda i soputstvuiushchim multifokalnym aterosklerozom [Efficiency of primary PCI in patients with myocardial infarction and concomitant multifocal atherosclerosis]. Candidate's thesis. Novosibirsk [in Russian].

9. Van der Wal, A.C. (2007). Coronary artery pathology. Heart, 93 (11), 1484-1489. DOI: 10.1136/hrt.2004.038364.

10. Fakhry, F., Spronk, S., van der Laan, L., Wever, J.J., Teijink, J.A., Hoffmann, W.H., ..., \& Hunink, M.G. (2015). Endovascular revascularization and supervised exercise for peripheral artery disease and intermittent claudication: a randomized clinical trial. JAMA, 314 (18), 1936-1944. DOI: 10.1001/jama.2015.14851.

11. Sabatine, M.S., Giugliano, R.P., Keech, A.C., Honarpour, N., Wiviott, S.D., Murphy, S.A., ..., \& Pedersen, T.R. (2017). Evolocumab and clinical outcomes in patients with cardiovascular disease. N. Engl. J. Med., 376 (18), 1713-1722. DOI: 10.1056/ NEJMoa1615664.

12. Strobl, F.F., Brechtel, K., Schmehl, J., Zeller, T., Reiser, M.F., Claussen, C.D., \& Tepe, G. (2013). Twelve-month results of a randomized trial comparing mono with dual antiplatelet therapy in endovascularly treated patients with peripheral artery disease. $J$. Endovasc. Ther., 20 (5), 699-706. DOI: 10.1583/13-4275MR.1.

13. (2014). Unifikovanyi klinichnyi protokol ekstrenoi, pervynnoi, vtorynnoi ta tretynnoi medychnoi dopomohy "Hostryi koronarnyi syndrom z elevatsiieiu sehmenta ST". Nakaz Ministerstva okhorony zdorovia Ukrainy [Ministry of Health of Ukraine. Unified clinical protocol for primary, secondary and tertiary care: "Acute coronary syndrome with elevation of the ST segment"]. No. 455 [in Ukrainian].

14. Ibanez, B., James, S., Agewall, S., Antunes, M.J., Bucciarelli-Ducci, C., Bueno, H., ..., \& Widimský, P. (2018). 2017 ESC Guidelines for the management of acute myocardial infarction in patients presenting with ST-segment elevation: The Task Force for the management of acute myocardial infarction in patients presenting with ST-segment elevation of the European Society of Cardiology (ESC). Eur. Heart J., 39 (2), 119-177. DOI: https:// doi.org/10.1093/eurheartj/ehx393.

15. Karpishchenko, A.I. (2001). Meditsinskaya laboratornaya diagnostika (programmy i algoritmy) Meditsinskiye laboratornyye tekhnologii i diagnostika [Medical laboratory diagnostics (programs and algorithms). Medical laboratory technologies and diagnostics]. Saint Petersburg: Intermedika [in Russian].

16. Douglas, P.S., Garcia, M.J., Haines, D.E., Lai, W.W., Manning, W.J., Patel, A.R., ...,\& Weiner, R.B. (2011). ACCF/ASE/ AHA/ASNC/HFSA/HRS/SCAI/SCCM/SCCT/SCMR 2011 appropriate use criteria for echocardiography. J. Am. Soc. Echocardiogr., 24 (3), 229-267. DOI: 10.1016/j.echo.2010.12.008. 
17. Papadopoulos, K., Lekakis, I., \& Nicolaides, E. (2017). The predictive value of the syntax score in patients with chronic coronary artery disease undergoing percutaneous coronary intervention or coronary artery bypass grafting: a pilot study. Open Cardiovasc. Med. J., 11, 28-32. DOI: 10.2174/1874192401711010028.

18. (2010). An international randomized trial comparing four thrombolytic strategies for acute myocardial infarction. N. Engl. J. Med., 329 (10), 673-682. DOI: 10.1056/NEJM199309023291001. 19. Rebrova, O.Yu. (2006). Statisticheskiy analiz meditsinskikh dannykh. Primeneniye paketa prikladnykh programm STATISTICA. [Statistical analysis of medical data. Application of the STATISTICA software package]. Moscow: MediaSfera [in Russian].

Отримано 27.08.2021

Електронна адреса для листування: dr.dobrianskyi@gmail.com

T. O. DOBRIANSKYI, M. I. SHVED, I. K. WENGER

I. Horbachevsky Ternopil National Medical University

\section{CLINICAL “PORTRAIT” OF A PATIENT WITH ACUTE CORONARY SYNDROME IN COMBINATION WITH CRITICAL ISCHEMIA OF THE LOWER EXTREMITIES AS A CRITERION FOR PREDICTING AND CHOOSING TREATMENT TACTICS}

The aim of the work: to determine the influence of atherostenotic lesions of the iliac-femoral arterial segment on the severity of the clinical course, laboratory changes, instrumental parameters and prognosis in patients with ACS (MI) with elevation of the ST segment. Materials and Methods. We examined 105 patients with ACS (MI) with elevation of the ST segment in combination with critical ischemia of the lowers extremities due to stenotic atherosclerosis of the iliac-femoral arterial segment (III-II HAI) and 38 patients with ACS (MI) with ST segment elevation without critical ischemia of the lower extremities (comparison group). In addition to general clinical, laboratory and instrumental methods, additional ECG, ultrasound of the aorto-iliac and femoral arterial segments, transthoracic echocardiography and CAG were performed to assess the severity of anatomical lesions of the VA. The risk of nosocomial mortality was predicted on the GRACE scale.

Results and Discussion. Middle-aged and elderly men (over 55 years old) predominate over women by gender qualification (10.7:1) and significantly more often has ACS (MI) in combination with critical ischemia of the lower extremities. They are characterized by the presence of comorbid conditions (hypertension, uncompensated type 2 diabetes, metabolic syndrome, chronic obstructive pulmonary disease and such risk factors for coronary heart disease as dyslipidemia, smoking, alcohol abuse and aggravated heredity.

Characteristic features of the clinical "portrait" of a patient with ACS (MI) with critical ischemia of the lower extremities is a severe general condition of the patient, which is due to the presence of combined multivascular coronary artery disease (4.78 times more often than in isolated ACS) and a large amount of myocardial necrosis, signs hypertrophy and remodeling with a significant decrease in systolic (PV less than $50 \%$ ) and diastolic functions. Frequent presence of life-threatening complications of the acute period of MI, arrhythmias and conduction and acute heart failure determined the prediction of a high risk of mortality on the GRACE scale (172.7 \pm 12.7$)$.

Key words: acute coronary syndrome; critical ischemia of the lower extremities; diagnosis; clinical manifestations; prognosis; treatment. 